\title{
TEN OF MARX'S IDEAS THAT SURVIVED THE 20TH CENTURY
}

Keywords:

Marx; emancipation;

exploitation; poverty; machine; fictitious capital.

Author:

Dr. Ivan Šijaković is a Professor of Sociology at the Faculty of Political Sciences of the University of Banja Luka, $B \mathcal{e} H$.

Correspondence:

ivan.sijakovic@fpn.unibl.org

Field:

Theoretical sociology

\section{Summary}

This paper analyses some of Marx's ideas and attitudes that have been the subject of debate, support, dispute and controversy during the 20th century. All these ideas, in the second decade of the 21st century, can be the basis for research, analysis and criticism of the same phenomena Marx spoke about 150 or 160 years ago. In this paper, we point out ten key ideas of Karl Marx that were theoretically important for the analysis of events and social changes during the XX and early XXI centuries.

DOI:

10.5937/politeia0-19911

Paper received on:

12.11.2018.

Paper accepted for publishing on: 


\section{INTRODUCTION}

The strength of Marx's ideas is reflected in their theoretical precision, their inspirational action and their long duration. It's been 200 years since Marx's birth and 135 years since his death, hence a long time to try once more to check the value of his ideas and attitudes in contemporary society. Marx's ideas influenced in two ways during the 20th century: First, they encouraged a variety of theoretical discourses in the fields of sociology, economics, anthropology, history and political science; Second, they inspired a multitude of social movements (workers, national-liberation, anti-colonial) who wanted to change society. It is known that this second direction of Marx's ideas had an impact on the outbreak of socialist revolutions and the emergence of the socialist social order.

In this paper, we present several of Marx's ideas and argue their importance in the 21st century. These ideas are important in the theoretical sense, for finding a concept in a society that has the same roots as in Marx's time, but these phenomena appear differently. We will not see them through the prism of Marxism as an ideology, but we will consider them as stand-alone, independent and analytically valuable sociological categories. Our methodological process consists of guiding Marx's original views, and then we will check their strength and capabilities to help us today in the analysis

\section{CRITIQUE OF EVERYTHING EXISTING}

In the Letter to Rugue, Marks emphasised the basic direction of his work in the future, which is "a ruthless critique of everything existing", ruthless in two senses : "The criticism must not be afraid of its own conclusions, nor of conflict with the powers that be" (Marks-Engels, 1989:52). Marx by critique of everything existing expresses his general relation to the theory, social events, institutions and the way of organising society. On the example of the state of religion and politics in Germany, Marx has shown that there are no ready-made models that can be offered, but that they should go from "a consistent critique of religion and politics", because it is only possible to seek concrete solutions for the state of the spirit, the idea and the entire societies in Germany (Marx-Engels, 1989). Engels in the critique of Feuerbach (Engels, 1947) noted well that politics (as theory and praxis) is a key link that prevents the progression of civic thought from superficial analysis and apologetics into critical thought. Bearing in mind the views of Karl Korsch (1972, 1975), we can conclude that Marx made a fundamental critique of "everything existing" in four phases: first, a critique of religion from the point of view of philosophy (old and new social consciousness); secondly, from the point of view of politics as the dominant practice, he criticised religion and philosophy; third, from the point of view of economics, he criticised religion, philosophy, politics and ideology; fourth, from the point of view of practice or practical human activity, he criticised religion, philosophy, politics (primarily the state), ideology, political economy, and "vulgar materialism". So, Marx criticised the society at the 
time, having in mind, above all, Germany as an empirical background, later to France, and eventually to England. By this, Marx established the foundations of a scientific critique of society.

Nowadays, such a critique should be subjected to a democracy, some views on human rights, liberalism, corporatism (corporatocracy), numerous theoretical approaches to globalisation, as well as geopolitical strategies, religion (religious fundamentalism), nationalism, economic development that exhausts non-renewable resources and destroys the environment, then financial derivatives, consumerism and the education system. Here, we will only indicate the direction of criticism of democracy, as due to the size of the text, we are unable to carry out the criticism of the other, mentioned elmenates.

We are aware of the numerous antinomies, weaknesses, fragility and limitations of democracy and its intertwining with totalitarianism (Lefort, 1988). The participation and interaction of citizens in contemporary democratic processes more and more leads to the "loss of the meaning of a political" (Howard, 2002). Democratic ideals and moral rules give way to national and religious identities, war threats, corruption and crime (Stout, 2005). The critique of democracy must be fundamental. This implies criticising the theory and the practice of democracy. A critique of the theory of democracy requires a "deconstruction of the contemporary notion of democracy," while the critique of practice encompasses the criticism of existing political systems and institutions that have emerged as a result of the application of doctrine (Tronti, 2009). Both of these historical dimensions of democracy (the practice of majority dominion and the doctrine of freedom) are in crisis nowadays and there is a conflict between them (Tronti, 2009), rather than cooperation and integration. The crisis of the basic theoretical concept of democracy, which related to the freedom, participation and equality of citizens is reflected in the fact that today we are talking about "a multitude of democracies" (Tronti), such as liberal democracy, socialist democracy, progressive democracy, deliberative democracy, minimal democracy, political, economic, social democracy and so on. All this points to the weakening of the concept and the idea of democracy. According to Iftode (2015), democracy does not appear to function as a concrete political practice, but as a projected experience and a messianic form without concrete content. In contemporary societies, throughout the world, there are deep gaps between the ethical core of democracy (as an instrument of freedom) and political practice based on manipulation and violence (Schwarzmantel, 2011).

\section{HUMAN EMANCIPATION}

Marx writes in On the Jewish Question, and in The Critique of Hegel's Philosophy of Right, that man's emancipation comes after civil and political emancipation. In fact, Marx speaks of four types, four phases of emancipation: first, religious emancipation, emancipation from religion (as "opium for the people") or self-alienation of a man in religion; secondly, the civil emancipation, demanded by Enlightenment, by means of separation of a civil society from the state, initiated by the French bourgeois revolution; third, political emancipation as a struggle against the denial of rights to some social subjects to participate in public affairs (women, Jews, minorities); fourth, "emancipation of mankind", social, 
human emancipation. In a discussion with Bruno Bauer, Marx concludes that in a society as it was then in Germany and in other parts of Europe, it is not possible to achieve a social, "emancipation of mankind", or a human emancipation, but only partial political emancipation. Here, Marx emphasised his well-known thought that "social emancipation of Jews is possible only as - emancipating of society from jewry." Only then will there be an "emancipating of the Germans into humans" (Marx, 1989: 88).

Unfortunately, Marx's attitude was called into question. Some authors even considered that there were elements of Marx's anti-Semitism within that attitude (Rockmore, 2002: 48-50). However, these authors did not understand that Marx was talking about the emancipation of society from jewish, as a stereotype, and not from Jews as people (as citizens). Marx asked the question as to why we only identify Jews with selfishness, egoism, greed, usury, blackmail, the accumulation of money and wealth, when it is inherent in other people. If we get rid of such practices, we will be able to achieve the emancipation of man. Marx points out that "man is the greatest being for man," giving the moral imperative for future human emancipation.

Nowadays we can say, paraphrasing Marx's idea of the emancipation of Jews, that the LGBT population can only be emancipated, by emancipating the society from "LGBTism". The same can be said for the emancipation of Rom, of feminists, of sports-hooligans, of nationalists and religious fundamentalists. "Emancipation of mankind" as human emancipation can only be achieved, nowadays, if one obtains "post-national citizenship" or "non-national citizenship" (Tambini, 2001; Bassok, 2004; Tonkinss, 2013). Another thing, one can only achieve emancipation with the help of technology, the most recent, sophisticated and versatile. Previous experiences (135 years after Marx) show that states, governments, political parties, movements, corporations, associations, NGO's are unable to achieve human, "general human" emancipation and full freedom. Why? Because there are two major obstacles. First, collective identities (hard identities: religious, national, political, ideological, and local) neglect and suppress a person, as an individual. There is no emancipation and freedom for man, as an individual, while captured in "self-alienation", in the collective identities. There is no emancipation of man where the citizens of one state are divided into members of the "dominant nation" and members of the "national minority" and if their political, civic and cultural participation and activity in society depends on it. Secondly, every form of human emancipation is disabled from: a high degree of poverty, crime, violence, corruption and nepotism in society.

\section{PRODUCTIVE FORCES AND RELATIONS OF PRODUCTION}

Production forces are the driving forces for the development of a society. The relationship between productive forces and relations of production is the basic law for the development of society and the foundation of sociology, economics and history as a science. The productive forces (means of production and labour) are "the basis of all human history," emphasises Marx in Letter to Anenko, because all other forms of human life depends on their development: the way of production, trade, families, class relations, culture, political ordering, and the general characteristics of a society. "The productive forces are the result of the 
practical energy of people, but this energy itself is conditioned by the circumstances in which people be situated, due to the already acquired forces and social relations that they did not create, but are the result of previous generations" (Marx, 1989: 433). This inheritance and further development of productive forces is a link between generations and the mechanism of building human history, the "history of mankind" (Marx), which is nothing but the development of productive forces and changing relations of production (ownership, organisation of a society and the type of authority) as a framework in which the production forces are pinned, developed and improved. Marx emphasises that "the social history of people, is always the history of their individual development, regardless of whether they know it or not". Material relations are the necessary forms in which each individual and collective activity of people is realised. But the material and economic relations in which people "produce, exchange, spend," and organise a social and political life are "transient and historical forms". They change depending on the development of productive forces, which are constantly looking for new economic, social and political frameworks of their development.

If we look at the beginning of the 21st century through the prism of Marx's theoretical discourse, we will see that informatics, robotisation and digitisation are new productive forces that change all the existing social relations (dictatorships, autocracy, theocracy, nationalism, and localism). The productive forces of the 21st century consist from the hardware, software, robots, 3D printers (printing clothes, buildings, human skin), nano technology, artificial raw materials, scientists, computer programmers, operators, engineers and web designers.
These productive forces changes existing, inherited relations of production formed in the industrial age, and bring to the scene a new type of society, known as information, cyber, digital or virtual society. The new productive forces require a new economy, new forms of organisation of society, new forms of government and governance, a new culture, a new moral and value principles.

\section{EXPLOITATION OF WORKERS}

The exploitation of workers, as Marx writes in Capital I and Engels in The Condition of the Working Class in England and Marx and Engels in The Communist Manifesto, are still present in contemporary societies, but in different circumstances and with other means of production. Marx wondered, "does the rented work, the work of the proletarian, create wealth and property for him?" He replied, "By no means. He creates capital in, that is, increases the capital of capitalists who exploit the rented work. Private ownership is increased only when the worker is exploited by capital. The hired worker and capital are in constant contrast: the capital increases more and more, the hired worker is reduced in absolute terms. The hired workers "are goods as well as every trade item and therefore are exposed to all conditions of competition and market fluctuations" (Marx, 1977: 475). The exploitation of workers continues to be continuously developed by the development of modern industry and further expanded by involving women and children in hired work. When the exploitation of the worker is completed at the factory and he gets his rent, then exploiters from other areas hit him: "landlords, traders, lenderses " (Marx, 1977: 475). 
From Marx's point of view, at the end of the 20th and the beginning of the 21st century, the analysis of the exploitation of workers (as well as other categories of employees) has to be shifted from the national to the global space. Today, multinational companies are the bearers of the exploitation of workers (employees). We will illustrate this in the case on the FIAT company from Italy. A worker at FIAT in Italy earns (on average) $€ 1,900$ a month, at the FIAT factory in Turkey, he earns $€ 900$, in Slovakia $€ 600$, and in Serbia, € 350 (FCA, 2017). We see that now, apart from owners and managers, a worker from Italy also participates in the exploitation of workers in Turkey, Slovakia and Serbia. Now we can set up a thesis on the phenomenon of the total exploitation of workers. The second example shows that there is regional exploitation in the EU. For example, there are differences in the degree of economic development between some EU regions on the scale of 1:30, such as Old Zagora in Bulgaria (1) and North Rhine Westphalia (30) in Germany (Eurostat, 2011). This example confirms the analysis of Imanuel Vallerstein that Europe, for centuries, has been developing according to the principle of center-half periphery-periphery (Wallerstein, 1986), with the centre always being in Western Europe, and that very rare movements of states are in this order.

\section{THE EXPANDING OF POVERTY}

The expanding of poverty, on the one hand, and the accumulation of wealth, on the other, appears as the basic dimension of the "capitalist mode of production", Marx points out, because "the position of the workers must be worse, with the accumulation of capital, and regardless of the worker being well paid or not" (Marx, 1977: 541).
All this leads to the collection of wealth on the one side, causing an "accumulation of misery, hard labour, ignorance, moral and spiritual decline on the other, workers' side". The expansion of poverty encompassed a number of social strata, as Marx testifies, "small and middle stocks, small industrialists, traders and renters, craftsmen and peasants, all falling to the level of the proletariat," because their small capital is insufficient to enter in the big industry, or their knowledge and skills are not useful for the new industrial mode of production (Marx-Engels, 1968). In his alalysis, Marx reveals that industrial development, scientific and technological discoveries, increased human efforts and work, do not lead to an improvement in the living conditions of an enormous mass of people. Marx reveals the fundamental contradiction that leads to poverty in capitalism: on the one hand, permanent industrial growth and "infinite accumulation of capital"; on the other hand, the endless misery of workers, their families and masses of other people.

Marx's idea about the incredible concentration of wealth during the industrial revolution is still current today. As Thomas Piketty notes (2015), Marx's view of the concentration of wealth during the industrial revolution and its principle of infinite accumulation "contain a key insight that is important for the analysis of the XXI century as it was in the 19th century" (22). Nowadays, there are more than 1 billion people living in the world on less than $\$ 1.9$ per day, and more than 2.5 billion people on less than $\$ 3.2$ per day, while $50 \%$ of people live on Earth with less than $\$ 5.5$ daily (World Bank, 2018). When we consider the wealth of the 60 richest people in the world (according to the Forbes list), we can see their wealth is greater than the "wealth" of 
3.5 billion people in the lower part of the world's demographic pyramid. Another example of wealth concentration: In Italy, the 300 richest families are worth two hundred and fifty percent more than the GDP of Italy (INVESTIREOGGI, 2017).

\section{CAPITALISM DESTROYS THE SOCIAL TISSUE OF MODERN SOCIETY}

This is one of the fundamental ideas Marx follows in the analysis of the development of society in the XIX century. Marx in Capital analyses the causes of the economic crises which capitalism created via their unnecessary exploitation of nature and man. Capitalism destroys the social structure of society by creating two opposing classes - bourgeoisie and proletariat. Capitalism destroys the family because it exploits all its members.

Nowadays, this thesis should be examined on the example of the XXI century society from an ecological, economic (especially financial), political and social point of view. The economic crises that appear are cyclically destroying some industries, some regions, states and local communities. There is a lot of literature that points to the harmful consequences of the liberalist (neo-liberal) phase of capitalism. Ulrich Beck talks about how globalisation and world politics are subtracted power to national politics and the nation state. He points out that we are in the "world risk society" and paraphrasing Hobs (homo homini lupus est) concludes that the political theory of a risk society starts from the principle "mankind to mankind lupus est" (Beck, 2004). Manuel Castells, warns us that the end of the Millennium and the beginning of the 21st century have led to a new polarisation of the world with rich and poor countries.
Then there was the dehumanisation of most African countries, the collapse and looting of the former socialist states, the rise of the "global criminal economy", and the accumulation of environmental problems in the big cities and megalopolises (Castells, 2003). Philippe van Parries (1997) reveals the greatest contradiction of contemporary liberal capitalism, saying that freedom in liberalism stands out as the greatest value, while modern capitalism creates the greatest inequality among people in the history of mankind.

\section{RELATIONSHIP BETWEEN MAN AND MACHINE}

In the first volume of the Capital, Marx mentions the automation of production, the role of the machine in creating surplus values, stressing that the machine releases the workers of hard work, but leaves them out of work, throws them out of the work process, also extends their working time and increases their exploitation. The productivity of the machine, emphasises Marx, is measured by degree to which it replaced human labour (Marx, 1977: 346). Marx notices the paradox in the relationship between man and machine, in that the machine "as the most powerful means of shortening working time is transformed into a means of transforming the worker's total time and the life of his family to working time available for accumulation and capital increase" (Marx, 1977 : 361). In this way, there is a specific phenomenon that the machine, which was supposed to be man's "friend and assistant," destroys all "moral and natural boundaries of working time" and turns workers into an object and a "conscious" supplement to the machine. Marx notes that the capitalist, as owner and capitalism as a system abuses 
the machine and transforms it, rather than using it as a means to improve human life, it destroys the conditions of the worker's existence. The machine "breaks down the price of labour below their value" and thus "the means of labour kills the workers" (Marx, 1977: 383). Marx concludes that all antagonisms between man and machine do not derive from the properties of the machine, but from its capitalist use.

In order to find a way to eliminate the contradiction between machine and man, Marx speaks of a "total worker" as a "social worker", ie, the "social working body" comprised of the one who constructs the machine, the one who makes the machine, workers with new skills working on new machines and workers whose skills are not sufficient, and they were driven out of the work process. All of them need to pay their rent via the increased productivity generated by the machine, but it is all appropriated by the capitalist.

All these questions about the relationship between man and machine are still current, because modern man is confronted with the robotisation of production and services, leaving millions of people out of work. More than two billion various jobs will disappear by 2030. It makes up almost $50 \%$ of the total in today's number. This will be primarily due to the development of technology, which is dominated by digitisation. Trucks and vehicles will be digitised and managed by robotic pilots. Education moves from classrooms to the Internet. Automatic production abolishes crafts and manufactures. Computers will alert the patient to changes in his organism, based on daily biorhythm monitoring, and robotic dentists will install the implants. 3D printers already prints human skin and organs, while drones deliver mail and various products. However, jobs, such as 3D designers, ecology jobs, genetic designers, stress developers, vertical farmers and intelligent footwear and clothes designers will experience an expansion in the coming decades (The Futurist, 2013).

The question arises: what can we do to prevent mass unemployment? It is vital to shorten working time, then continually improve education, as well as introduce a primary income for all unemployed.

\section{FICTITIOUS CAPITAL}

Analysing the flows of money and capital in the mid-nineteenth century, Marx notices a new phenomenon as far as money is concerned, not only as a means of payment, where goods are sold for money, but money is exchanged for money, that is the beginnings of trading with money. Marx talks about new types of capital: "credit capital", "lending capital", "interest-bearing capital", "bill of exchange capital" as a types of "financial alchemy" that doubles and triples capital through interest and credit systems, making it fictitious instead of real. The loans, checks, bills and numerous small deposits "unite large sums of money and thus form the money force they have at their disposal" (Marx, 1974: 339). Thus, the money from "trading turnover goes into general circulation" and becomes a means by which it is traded in a special way (trade with credits, bills and checks). Marx notes that different conditions can cause demand for money and capital: insufficient production, excessive stockpiling, the desire to send goods to markets in India and China, and the like. This demand can not be covered by real money, for this reason the mechanism of the fictitious capital is launched: the loans; bills of exchange that circulate for months from 
one company to another, before they turn into money and sometimes do not get to become "real money"; then checks and various other forms of borrowed money. Marx states, it is often not possible to determine how much money comes from "real sources, actual purchases and sales, and which part is fictitious" and consists of a circulation of bills of exchange, deposits and checks, thus transferring "property from hand to hand and without the help of money "(Marx, 1974: 338-341). Marx clearly saw the use of the fictitious capital. Namely, the state collects real money from citizens and gives them bills with a certain, very attractive interest. The problem is that the state turns real money into "magnificent villas and the purchase of cannons" and thus, it becomes "irretrievably lost" money. Instead of real money, citizens have only "papers with a right to ownership". All of these papers, Marx calls "paper duplicates of a destroyed capital” (Marx, 1974: 355).

On the trail of Marx's forecast, one should analyse the state of "virtual money", which in the world economic space is 17 times more than the world's GDP (Elsässer, 2009: 35). It is clear, Elsässer accentes, that this "fictitious capital" does not arise from material production or from concrete services, but as the very root of the Latin word says (derivare) "was created as a result of the work of financial magicians". Elsässer points out that Marx could not even assume that, beginning in the 1970s, the US economy and other developed countries would be backed by fictitious capital. It was especially difficult to assume that "private financial sharks will in our time put into circulation duplicates of non-existent capital in the form of derivatives, which is much higher" than could have been held by governments in Marx's time, or governments of most countries in our time (Elsässer , 2009: 37). It is known that financial derivatives caused a crisis in Southeast Asia (Taiwan, Hong Hong, Singapore, Malaysia) in 1998, as well as a major financial world crisis in 2007-2009. Therefore, Elsässer named these derivatives (hedge funds, CDS, options, futures, unsecured loans) as "financial weapons of mass destruction" (Elsässer, 2009: 38).

\section{MARX AS PREDECESSOR FOR THE IDEA OF GLOBALISATION}

Marx suggests the possibility of internationalising productive forces and globalisation through the revolutionary role of new technologies that will allow a radical leap from "the realm of necessity to the realm of freedom". Marx pronounces that a large industry has created a world market that began with the discovery of America. The world market has enabled the enormous development of trade, seafaring and land communications. This development has further affected the expansion of industry. The expansion of industry, trade, maritime affairs and railways contributed to the the rise of the bourgeoisie. "In barely a century of class rule, the bourgeoisie has created more massive and colossal production forces than all the previous generations together." We see, therefore, that the modern bourgeoisie itself is a product of a long developmental path, a series of upheavals in the way of production and traffic.

Wherever it came to power, "the bourgeoisie destroyed all feudal, patriarchal and idyllic relations. The bourgeoisie, with all its past activities, viewed with pious fear, removed the illusion of holiness. It turned doctors, lawyers, priests, poets and scientists into paid hired workers. The 
bourgeoisie removed the sentimental blanket from family relationships and turned these relationships into pure financial relations. By exploiting the world market, the bourgeoisie gave a cosmopolitan form to production and consumption in all countries. She pulled the national soil out from under the industry's feet" (Marx-Engels, 1988: 15). Marx further recalls that the ancient national industries were destroyed and are continuing to be destroyed every day. "They are pushed by new industries whose introduction is a matter of survival for all civilised nations, industries that no longer process domestic raw materials, but raw materials coming from the furthest zones and whose products are not consumed only in the country in which they are produced, but simultaneously in all parts of the world "(Marx-Engels, 1988: 17). Changing the technology and mode of production also changes human needs. Instead of the old needs, which are satisfied by domestic products, new needs come in, which are only satisfied with products from the furthest countries and climatic areas. In place of the old local and national self-sufficiency and separation, versatile traffic enters, the versatile interdependence of all nations.

We clearly see that Marx has uncovered key elements that make up the present process of globalisation. These elements are: the development of technology; world trade; bringing all professions to a position of dependence; a constant change in human needs and a loss of influence and autonomy of national states. These elements nowadays need to add virtual communication and virtual space, and instead of the bourgeoisie, include scientists and technologists, as subjects of globalisation and contemporary social changes.

\section{MARX'S VIEWS ON NATURE AND MAN AS THE SOURCE OF THE FOUNDING OF ECOLOGY AS A SCIENTIFIC FIELD}

Marx's views on ecology begin with the debate about man as a natural being, as well as his alaza of the impact of capitalist industrial production on the destruction of nature. These views represent the starting point for today's discussions on the ecological problems of the contemporary world. Marx in Economic-Philosophical Manuscripts says that nature is a human's inorganic body and that he must remain with her in a continuous relationship until it dies. "Plants and animals, stones, air and light are not just material, object and instrument of human practical activities for obtaining food, clothing, shelter, heat and other needs. They are also objects of man's spiritual nature "(Marx-Engels, 1989: 247). So, nature is the source of man's existence, man's work, and man's scientific and artistic creativity. Marx notes that man's physical and spiritual life is "bound by nature, that is, nature is connected with itself, because man is part of nature". There is no better and more inspiring ecological statement of man's place in nature than this (H. L..Parsons, 1977).

The domination of private property and money, as Marx writes, change the perception of nature and represent it as an object of infinite exploitation. Such a relationship with nature means the practical degradation of nature. "Nature was here before the human race and every individual, and she has its own objective laws that govern us", and if we violate these laws, we bring ourselves to danger. According to Marx (1989: 249), "depletion of soil, forest surfaces, coal mining, iron and the like, by the industry and trade," mean that for capitalism, a quick 
profit is more important than the welfare of people or the maintenance of the fertility of the country.

\section{CONCLUSION}

In this paper, we presented ten of Marx's ideas, because we consider them to be as important for the analysis of society in the 21 st century, as they were in the 19th century. We are aware that there are many more of Marx's ideas and theoretical attitudes that are important for social sciences in the 21st century. We will only mention alienation, class, class struggle and class consciousness, criticism of ideology, then numerous economic analyses, as well as the dialectical method. It can be said that rare theoreticians are in the social sciences, whose ideas are inspirational and 200 years after their death, Marx is one of them.

\section{REFERENCES}

Basok, T. (2004). Post-national citizenship, social exclusion and migrant's rights: Mexican seasonal workers in Canada. in. Citizenship Studies 8(1):47-64

Beck, U. (2004). Moć protiv moći u doba globalizacije. Zagreb: Školska knjiga.

Castells, M. (2003). The end of Milenium. Zagreb: Golden marketing.

Dick, H. (2002). The Specter of Democracy. New York: Columbia University Press.

Eurostat (2011). Methodologies \& Working papers. URL: https://ec.europa.eu/eurostat/ documents/
Elsässer, J. (2009). Nacionalna država i fenomen globalizacije. Beograd: Jasen.

Engels, F. (1947). Ludvig Fojerbah i kraj klasične nemačke filozofije. Beograd: Kultura.

FCA - Fiat Chrysler Automobiles. (2017). Company web site.

The Futurist (2013). September-October.

Iftode, C. (2015). Postmodern Ethics, Multiple Selves, and the Future of Democracy. in. Journal for the Study of Religions and Ideologies. Winter.

Investireoggi. (2017). Quotidiano, economico finaziario, Luglio.

Korš, K. (1975). Materijalističko shvatanje istorije. Beograd: BIGZ.

Korš, K. (1972). Karl Marks. Beograd: Nolit.

Marx, K., Engels, F. (1988). Manifest Komunističkepartije.Zagreb: ECONOMICS.

Marx, K., (1989). Pismo Anenkovu. u: Marx, K., Engels, F. Rani radovi. Zagreb: Naprijed.

Marx, K., (1977). Kapital I. Beograd: Prosveta.

Marx, K., Engels, F. (1989). Rani radovi, Zagreb: Naprijed.

Marx, K., Engels, F. (1968). Manifest komunističke partije. Beograd: Reč i misao.

Lefort, C. (1988). Democracy and Political Theory. Cambridge: Polity Press. 
Parsons L. H. (1977). Marx and Engels on Ecology. Westport, CT: Greenwood Press.

Piketty, T. (2015). Kapital u XXI veku. Novi Sad: Akademska knjiga.

Philippe, van P. (1997). Real Freedom for All: What (If Anything) Can Justify Capitalism? Oxford: Clarendon Press.

Rockmore, T. (2002). Marx after Marxism. London: Blackwell Publishers Ltd.

Schwarzmantel, J. (2011). Democracy and Political Violence, Edinburgh: Edinburgh University Press.

Stout, J. (2005). Democracy and Tradition. Princeton: Princeton University Press.

Tambini, D. (2001). Post-National Citizenship. in. Ethnic and Racial Studies 24(2).

Tonkiss, E. K. (2013). Post-national citizenship without postnational identity? A case study of UK immigration policy and intraEU migration. in. Journal of Global Ethics, April.

Tronti, M. (2009). Towards a Critique of Political Democracy. in. The Journal of Natural and Social Philosophy. Vol. 5. Issue 1 .

Wallerstein, I. (1986). Suvremeni svetski sistem (The Moder World System). Zagreb: CEKADE.

The World Bank report (October, 2018). Official site. 


\section{ДЕСЕТ МАРКСОВИХ ИДЕЈА КОЈЕ СУ ПРЕЖИВЈЕЛЕ ДВАДЕСЕТИ ВИЈЕК}

Кључне ријечи:

Маркс; еманиипација;

израбльввағе; сиромаштво; машине; фиктивни капитал.

Аутор:

Др Иван Шијаковић је професор социологије на Факултету политичких наука Универзитета у Баној Луци, БиХ.

Коресподенција:

ivan.sijakovic@fpn.unibl.org

Област:

Теоријска социологија

DOI:

10.5937/politeia0-19911

Датум пријема чланка:

12.11.2018.

Датум прихватања чланка за објављивање:

15.12.2018.

\section{Сажетак}

У овом раду анализирају се неке од Марксових идеја и ставова о којима се расправть а током 20. вијека и које представльају контроверзне теме, које неки аутори подржавају а неки оспоравају. Све ове идеје могу да представльају, у другој декади 21. вијека, основу за истраживаюе, анализу и критику истих појава о којима је Маркс говорио још прије 150 или 160 година. У том погледу, истичемо десет клучних идеја Карла Маркса које су биле битне у теоријском смислу за анализу догађаја и друштвених промјена током 20. вијека и почетка 21. вијека. 